\title{
Usefulness of Green Marketing-Literacy and Purchase Decisions
}

\author{
Dr. Shakeel-Ul-Rehman \\ Lecturer \\ Department of Business Administration Govt. Degree College, Kulgam-192231, Jammu \& Kashmir, India,
}

\begin{abstract}
Let every individual and institution now thinks and acts as a responsible trustee of the Earth, seeking choices in ecology, economics and ethics that will provide a sustainable future, eliminate pollution, poverty and violence, awaken the wonder of life and foster peaceful progress in the human adventure".

John McConnel (Founder of International Earth Day)

As the components of our environment are dynamically dependent and interrelated, even a small change in its equilibrium will have serious consequences on mankind. The functioning of our ecosystem is hampered by various types of pollution resulting from anthropogenic activities, which in turn impacts life of any kind. It is time to realize our responsibilities towards nature and reduce our damage to the environment. No other creature of nature is altering the environment as human being is changing it by its selfish motives to satisfy his short term requirements and benefits. While manis in the progress of sustainable development, by sacrificing the natural environment it is not possible to attain it.One effort towards saving the environment has originated the concept of green marketing in modern business. Green marketing focuses on saving the earth's resources in production, operating,packaging, transporting, delivering etc., for environmental compatibility with performance, affordability, convenience and environmental safety. The paper interests to share the usefulness of green marketing and to know the awareness, liking and satisfaction of people about green marketing. A survey was done in two cities of TamilnaduSalem and Coimbatore with a sample of 200 selected customers through convenience sampling technique from different grocery stores and shopping malls in order to get an insight into the concept.The study revealed that the green products have substantial awareness amongcustomers and they are willing to buy and pay for green products. Customers also considered awareness and availability of green products as an important deciding factor in promoting green marketing.
\end{abstract}

Keywords: Awareness, Environment, Green Products, Green Marketing, Responsibility

\section{Introduction}

"The sun, the moon and the stars would have disappeared long ago ...... had they happened to be within the reach of predatory human hands".

Havelock Ellis

Green Marketing includes all activities like production and marketing designed to generate and aid exchange intended to satisfy human needs and wants, in a manner that is less unfavorable to the environment with growing awareness about the implications of global warming, non-biodegradable substances, harmful impact of pollutants etc., both marketers and consumers must become increasingly sensitive to the need for switch in to green products and services. While the shift to "green" may appear to be expensive in the short term, it will definitely prove to be indispensable and advantageous, cost-wise too, in the long run (Mohanasundaram, 2012). A society becomes more concerned about environment when it experiences some environment problems like pollution of air, water and land, extinction of some endangered species, spread of diseases in the society, depletion of natural resources due to overexploitation. Before all this happen our society must have a concern toward the environment to protect it against any overexploitation and misuse. Environment friendly marketing balances the environment compatibility with performance, affordability and practicality. Some companies have taken the initiative to save the environment and their desire to maintain competitive position in the market. The concept should bring all the companies in the jurisdiction of environmental safety. Both the consumer as well as the company must be aware about their role for the environment and must not forget their responsibilities. Examples of companies like Xerox's Revive 100\% Recycled paper, fuel efficient bikes from Hero Motor Corporation, replacement of clamshell packaging with waxed paper by McDonald, Carbon-Neutral by HSBC, recycle strategy by Coca Cola etc. have really boosted the movement of producing and marketing ecofriendly products. Other companies who claim green marketing efforts are HLL's Surf Excel; save two buckets of water every day, Energy saver refrigerators Air Conditioners and other electric equipments in consumer durables from companies like LG, Videocon, Samsung, Godrej, Kelvinator etc., unleaded petrol by BP, Shell, HP, IOC etc., Energy saver tube lights from Philips,Havels, Panasonic etc., ONGC'sMokshada Green Cremation initiative is saving 60 to $70 \%$ of wood and a fourth of the burning time per cremation. Green banking- first solar-powered ATM by IndusInd bank,IDEA, paints India green with its national 'Use Mobile, Save Paper' and save the trees campaign. TNPL makes paper primarily from Bagasse, namely sugarcane waste 
using as little wood as Possible. ITC has strengthened their commitment to green technologies by introducing 'Ozone-treated elemental chlorine free' bleaching technology for the first time in India and sells classmate ecofriendly notebooks, Suzlon Energy produces wind power to save nonrenewable resources. These initiatives of green marketing by the companies have really proven worthy and have won the trust of so many people. As awareness level of people about green marketing increases they start searching and using green products. The green consumer is further defined as one whoadopts environmentally-friendly behaviors and/or whopurchases green products over the standard alternatives(Vernekarand Wadhwa, 2011).So a person who purchases, uses or consumes a green product is a called as a green consumer.

\section{Background And Literature Review}

Without adequate environment protection, development is undermined. Without development, resources will be inadequate for needed investments, and environment protection will fail. In short, promoting development and protecting the environment are complementary.

World Development Report, 1992

In 1972, United Nations Conference on Human Environment was held in Stockholm, the theme of the conference "Only One Earth" was chosen to emphasize that all living and inanimate things among which man dwelt, were part of a single interdependent system, and that man would have no other place to live if he ruined his surroundings through his selfish abuse of the environment. People have learned lessons and history is the evidence of such disasters which created havoc in the society. Large scale discharge of Methyl-Mercury by Chisso Corporation into Minamata Bay between 1932 and 1968 caused MinamataTragedy in the island of Kyushu, Japan, which was responsible for Minamata disease causing widespread damage in the central nervous system in aqueous as well as human life. Mercury caused contamination of fish which entered in the food chain and about 1043 people died and another 2252 were infected. Chisso was held in trial and had to pay huge sum of money as penalty to damage the environment.

Worst chemical disaster in the world in December 1984 caused the Bhopal Gas Tragedy, leakage of Methyl Isocyanate Gas from a Union Carbide Plant in Bhopal, 10,000 people were killed and 20,000 more were injured.The explosion of Nuclear Power Plant at Chernobyl, Ukraine during 1986 released thirty to forty times the radioactivity of the atom bombs dropped on Hiroshima and Nagasaki. In February 1996, Sea Empress an Oil tanker, carrying 1,40,000 tons of light crude oil, ran ashore off Milford Haven in Wales, leaking over half of her cargo into the coastal waters. The spill threatened not only the local marine life, but also livelihoods of hundreds of local people.

In last 35 years the Kasargod province, where aerial spraying of Endosulfan occurred, Endosulfan has been linked to hundreds of deaths and health disorders among Cashew nut plantation workers and villagers in Kerala, India.Case of leather Tanneries in Tamilnadu, where untreated effluents are diverted into agricultural fields, road sides, waterways and open lands, leading acute shortage of drinking water in 59 villages and degradation of agricultural land leads to crop failures. Tirupur Hosiery alleged for dumping untreated wastes into the river Noyyal, a tributary of the river Bhavani causing pollution of irrigation water. The local people complained and more than 600 dyeing and bleaching units were closed by Madras High Court.

All the above environmental issues have not only damaged the environment but have smashed many lives of plants, animals and humans both on land, air and water. As man has become more materialistic, it is high time to realize the value of nature and man is the only creature that should be mostly responsible for its safety. He should try to create and develop the green environment everywhere. In context to this, various literatures have addressed the researchers about the initiative and initiated the process of analyzing the green marketing.According to American Marketing Association, "Green Marketing is the marketing of products that are presumed to be environmentally safe. Green marketing refers to the process of selling products and/or services based on their environmentally friendly or packed in environmentally friendly way.

Balderjahn, (1988) found that a positive attitude toward ecologically conscious living resulted in ecologically-responsible buying and using of products, including the use of automobiles. It also prompted consumers to publicly show environmental concern by signing ecologically relevant petitions and supporting or joining an antipollution organization. Johri and Kanothip, (1998) argues that there is a growing body of knowledge on green marketing focusing mainly on four issues. These issues are: first, relevance of green marketing; second, impact of green marketing on firms' competitiveness and performance; third, attributes considered by consumers while buying green products; and fourth, improving effectiveness of green marketing.

If the major benefits of green products, comparedto the major costs are higher, then consumers will bemotivated to purchase these products even if they arepriced somewhat higher than non-green substitutes(Kotler and Zaltman, 1971).Gadekar and Gadekar, (2012) stated that the customers may not believe in the firm's strategy of green marketing, the firm therefore should ensure that they convince the customer about their green product, this can be done by implementing Eco-labeling schemes.In developing awareness of a green product, companies attempt to augment consumer knowledge of the product and its environmental attributes in 
the hope of bringing about purchase behaviour. However, the exact nature of the relationship between environmental knowledge and environmentally sensitive behaviour is still to be established (Arbuthnott andLingg, 1975).(Gadenne, 2011; Wulf and Schroder, 2003) recommended that in order to predict specific behaviors the attitudes measured have to be directed at a specific environmental issue like purchasing of green products. There is a resultant increase in the concern expressed towards environmental protection leading to "green consumerism" (Eriksson, 2002).

Research in the last decade (Lee, 2009; Rahbar and Wahid, 2011; Lee,2008) has indicated that consumer are aware and are willing to pay more to "go green".Consumer awareness might be useful when the manufacturer's objective is to overcome resistance to new environmentally safe packages. Advertising of the new advantages and benefits of such products helps its consumers to become more conscious of the damage to the environment and they have a tendency to change their buying habits. Unless consumers are aware of the advantages of green products, manufacturers ${ }^{\text {ee }}$ effort to introduce this product to the market will be wasted efforts (Kassaye andDharmeda, 1992). Thoughts (cognitive function) and feelings (affective function) are directly impacted by the attitude people show hence it has impact on their overall perception of purchase related behaviour (Hoyer and MacInnis, 2004).

Rashid, (2009) has identified that when consumers are aware of eco labels they react more positively towardsknowledge of green marketing and the purchase of green products.There is a need to identify theimpact eco labeling will have directly on the consumer environmental attitude in terms of decision making. Theconsumer awareness of eco labeling and its impact on consumer intent to purchase an eco friendly product hasbeen researched and conflicting views have been expressed (Rashid, 2009; Lyer, 1999).Green marketing subsumes greening products aswell as greening firms. Though normative concernsimpact consumers' and firms' decision making,economic aspects of green marketing should not beneglected. Managers need to identify what ought to be greened: systems, processes or products? Consumerapathy to green products is due to many factors,including inadequate information about levels ofgreenness, lack of credibility of firms' claims and thetendency to free ride. (Vernekarand Wadhwa, 2011).

Roy, (2012)in his survey states that so far as the awareness about green products is concerned, overwhelmingly more than 70 percent of respondents claimed they were aware a lot of the green products. Only a small proportion of respondents had a less awareness about the green products (15.7 percent). On the other hand, 13 percent of them admitted they had never heard about green products. Overall, respondents in the study are aware of the green products and have a positive attitude towards the products. They are also confident about the future prospects of the products. Similar study by made by Simintiras, et al., (1994) recalled that $42 \%$ of UK consumers chose products on the basis of their environmental performance and that $27 \%$ of British adults were prepared to pay up to $25 \%$ more for "environmentally friendly" products and Ottman,(1993) found that green product introductions in the US more than doubled to 11.4 percent of all new householdproducts between 1989 and 1990, and continued to grow to13.4 percent in 1991. Similarly, the volume of green print ads grew by 430 percent and that of green TV ads by 367 percent, between 1989 and1990. Many consumers demand environmental responsible and friendly items on shelves and in this case the marketers have to build up competitiveness in respect to such consumer purchase behavior (Follows and Jobber, 2000). The results of study by Subhani, et al., (2012) comprehended that males would prefer environmentally friendly brands if they are concerned about the environment and their perception about a brand being environmentally friendly. While females prefer environmentallyfriendly brand if they are socially influenced and/or has concern about the environment.

\section{Methodology}

The study used structured questionnaire as survey method for getting the response on diverse variables of green marketing. Questionnaire was distributed to the respondents, who purchase products from various grocery stores and shopping malls, in the two cities of Tamilnadu; Salem and Coimbatore by Convenience Sampling Technique. Besides the Demographic Factors the respondents were asked to rate each item on a 5point,Likert scale from $1=$ strongly disagree to $5=$ strongly agree. Hair et al., (1998) stated that reliability estimates between 0.60 and 0.70 represent the lower limit of acceptability in quantitative research studies. Due to the exploratory nature of this research, alpha value is greater than 0.60 for reliability estimates and is considered adequate. Data was further tested by Optimal Scaling Technique through SPSS software in order to derive conclusions on the responses.

\section{Necessity of the Study}

Wealth without Social Responsibility, Pleasure without Conscience, Religion without sacrifice, Politics without Principle, Knowledge without Character, Science without Humanity and Business without Ethics will destroy society.

M.K. Gandhi 
The main aim of the study is to know usefulness of green marketing and how different variables contribute in making green product purchase decisions in customer point of view.

\section{Analysis, Discussions And Findings}

\section{Hypotheses}

H0: There is no association between "You will Recommend Green Products to Others" and Age (in years), Gender, Educational Qualification, Marital status, Main occupation, Family Annual income (in Rs), Awareness of Green products, Availability of Green products, Accessibility to Green products, Availability of Green Product with green packaging, Availability of Green product promotions, Affordable price of Green products, Awareness on harmful consequences of Non Green products on Environment, Prefer to purchase Green products in future.

\section{Optimal Scaling}

Fifteen variables have been correlated as shown in Table 1. The model summary shows a high correlation of 52.2 percent between the independent and dependent variables. The dependent variable observes an influence or variation of 14.8 percent (although not much) by the independent variables or explanatory/predictor variable. Moreover the ANOVA results provided in Table 1 shows that F-Test of the overall model is significant at 5\% level, again indicates that the regression model predicts the outcome variable significantly well.

Table 1.Model Summary and ANOVA

\begin{tabular}{|l|c|c|c|c|c|}
\hline & $\begin{array}{c}\text { Sum of } \\
\text { Squares }\end{array}$ & df & Mean Square & F & Sig. \\
\hline Regression & 54.416 & 29 & 1.876 & 2.191 & 0.001 \\
\hline Residual & 145.584 & 170 & 0.856 & & \\
\hline Total & 200.000 & 199 & 0.522 & \\
\hline Multiple R & \multicolumn{7}{|c|}{0.272} \\
\hline R Square & \multicolumn{7}{|l|}{0.148} \\
\hline Adjusted R Square & \multicolumn{7}{|l|}{}
\end{tabular}

Dependent Variable: You will recommend Green products to others, Predictors: Age (in years), Gender, Educational Qualification, Marital status, Main occupation, Family Annual income (in Rs), Awareness of Green products, Availability of Green products, Accessibility to Green products, Availability of Green Product with green packaging, Availability of Green product promotions, Affordable price of Green products, Awareness on harmful consequences of Non Green products on Environment and Prefer to purchase Green products in future.

If $p<0.05$, there is a significant association between the variables. In the Table 2 Coefficients, provide us with information on each predictor variable. It is clear that there is a positive as well as negative correlation between the dependent variable and independent variables. While looking at the sig. column the researcher can accept or reject the null hypothesis based on the significance level.

Table 2. Coefficients

\begin{tabular}{|c|c|c|c|c|c|c|c|}
\hline \multirow[b]{2}{*}{ Variables } & \multicolumn{2}{|c|}{$\begin{array}{l}\text { Standardized } \\
\text { Coefficients }\end{array}$} & \multirow[b]{2}{*}{ df } & \multirow[b]{2}{*}{$\mathbf{F}$} & \multirow[b]{2}{*}{ Sig. } & \multirow{2}{*}{$\begin{array}{c}\text { Tolerance } \\
\text { After } \\
\text { Transformation }\end{array}$} & \multirow[t]{2}{*}{ Null Hypothesis } \\
\hline & Beta & Std. Error & & & & & \\
\hline Age (in years) & 0.257 & 0.088 & 3 & 8.567 & 0.000 & 0.557 & Rejected \\
\hline Gender & 0.043 & 0.073 & 2 & 0.347 & 0.708 & 0.809 & Accepted \\
\hline Education & -0.015 & 0.070 & 1 & 0.046 & 0.830 & 0.886 & Accepted \\
\hline Marital status & 0.207 & 0.086 & 2 & 5.803 & 0.004 & 0.581 & Rejected \\
\hline Main occupation & 0.054 & 0.073 & 1 & 0.553 & 0.458 & 0.804 & Accepted \\
\hline Family Annual income (in Rs) & -0.249 & 0.073 & 2 & 11.608 & 0.000 & 0.801 & Rejected \\
\hline Awareness of Green products & -0.190 & 0.082 & 2 & 5.436 & 0.005 & 0.643 & Rejected \\
\hline Availability of Green products & 0.120 & 0.086 & 2 & 1.955 & 0.145 & 0.583 & Accepted \\
\hline Accessibility to Green products & 0.243 & 0.084 & 3 & 8.355 & 0.000 & 0.605 & Rejected \\
\hline $\begin{array}{l}\text { Availability of Green Product with green } \\
\text { packaging }\end{array}$ & -0.211 & 0.068 & 2 & 9.592 & 0.000 & 0.927 & Rejected \\
\hline Availability of Green product promotions & -0.086 & 0.071 & 2 & 1.486 & 0.229 & 0.853 & Accepted \\
\hline Affordable price of Green products & -0.159 & 0.070 & 2 & 5.224 & 0.006 & 0.881 & Rejected \\
\hline $\begin{array}{l}\text { Awareness on harmful consequences of } \\
\text { Non Green products on Environment }\end{array}$ & 0.109 & 0.070 & 4 & 2.379 & 0.054 & 0.862 & Accepted \\
\hline $\begin{array}{l}\text { Prefer to purchase Green products in } \\
\text { future }\end{array}$ & 0.202 & 0.070 & 1 & 8.460 & 0.004 & 0.884 & Rejected \\
\hline
\end{tabular}


Dependent Variable: You will recommend Green products to others.

Moreover the tolerance level of all the variables is below the maximum acceptable limit, so all the variables qualify for the above test.

\section{Transformation}

The transformation charts in Fig. 1 developed by SPSS through Optimal Scaling Technique presented below gives us an understanding of customer's response on various factors of Green Marketing Literacy and Purchase decision. It can be viewed from the transformation charts that mostly the respondents have rated the factors on positive side of the Five Point Likert Scale varying between 5-Strongly Agree to 1-Strongly Disagree. It is obvious to note that all the curves qualify towards positive end of the scale.
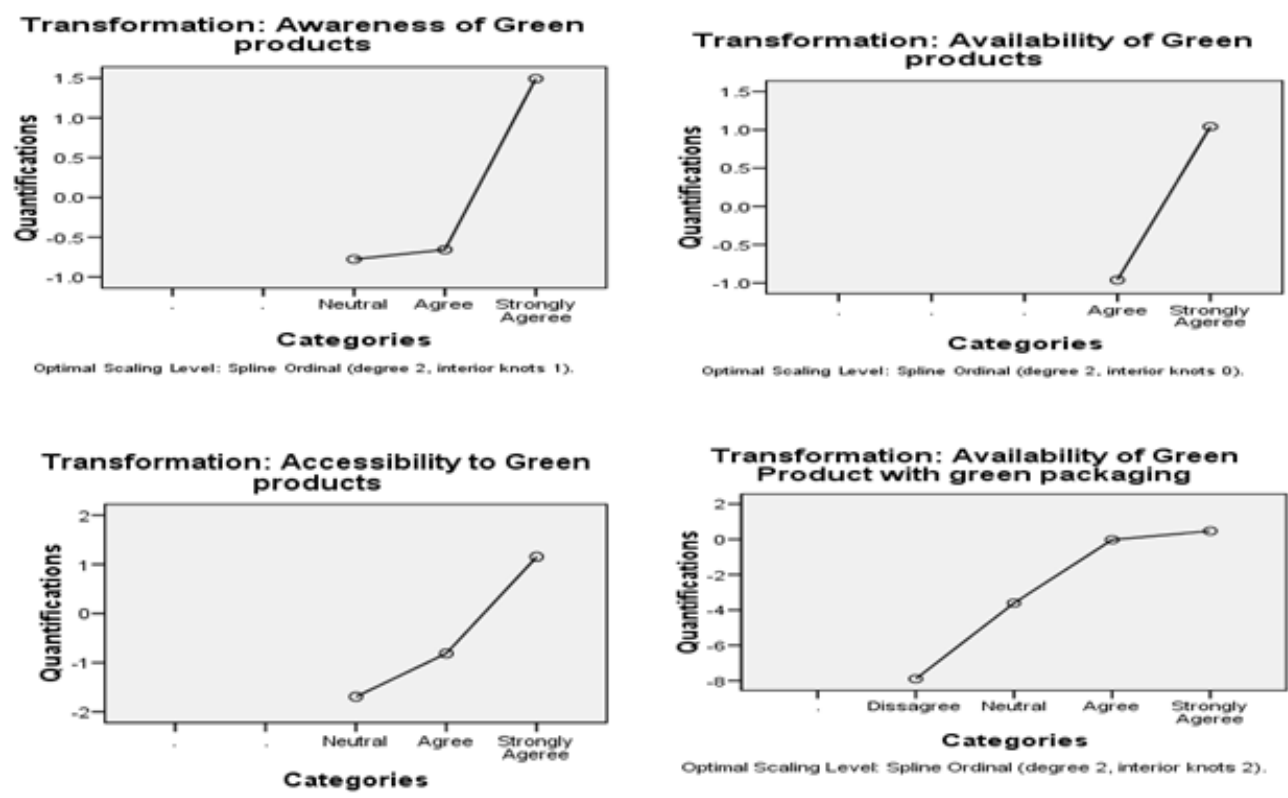

Transformation: Availability of Green product promotions
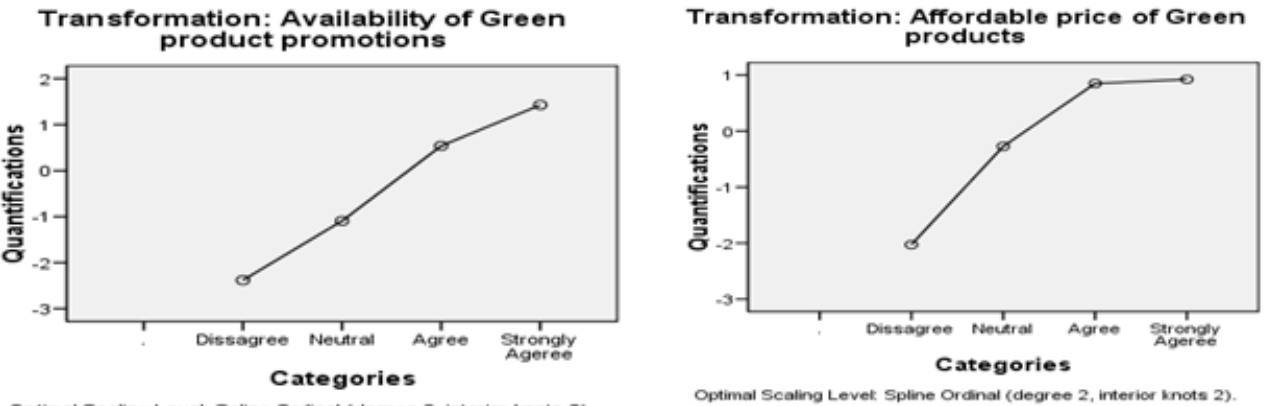

Optimal Scaling Level: Spline Ordinal (degree 2 , interior knots 2)
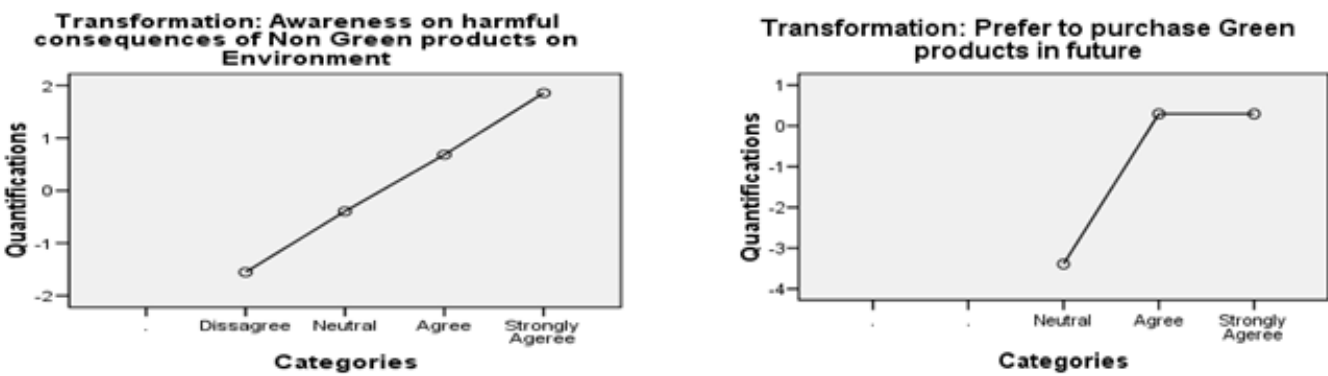

Optimal Scaing Levet Spline Ordinal (degree 2, interior knots 1 ).

Figure 1: Transformation Charts 


\section{Residuals}

From the residual plots developed by SPSS through Optimal Scaling Technique in fig. 2, where the "Recommendation of Green Products by the Customers to Others" has been related with "Demographic Profile of the Respondents", it can be observed that the scale has obtained an overall positive score from all the group items in the scale of demographic variables. It can be viewed that there are no outliers of data points in the plots and very few or negligible knots in unnormalized quantifications (see the curve in the plots is below 1) can be seen in the respective plots. It indicated that data is distributed normally and most of the respondent groups have rated the items positively under the given scale.

Residuals: Age (in years)

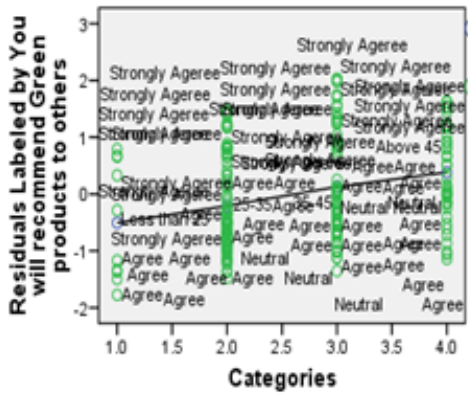

Optimal Scaling Level: Spline Ordinal (degree 2, interior knots 2)

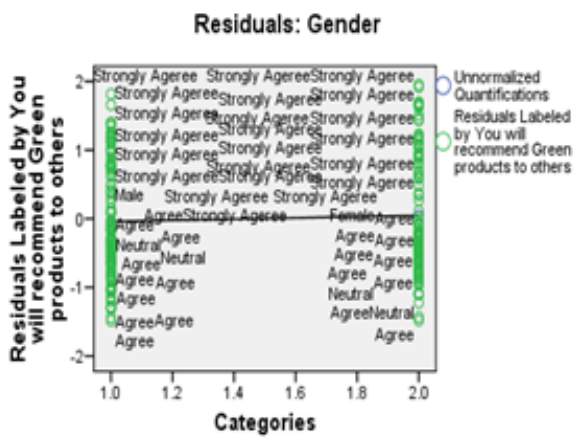

Optimal Scaling Level: Spline Ordinal (degree 2, interior knots 0).

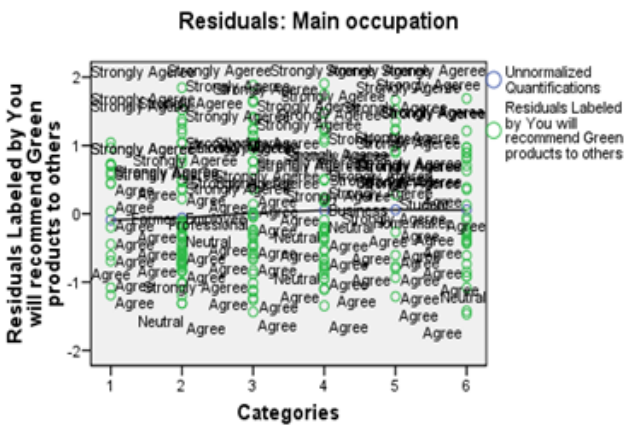

Optimal Scaling Level: Spline Ordinal (degree 2, interior knots 2).

Residuals: Family Annual income (in Rs)

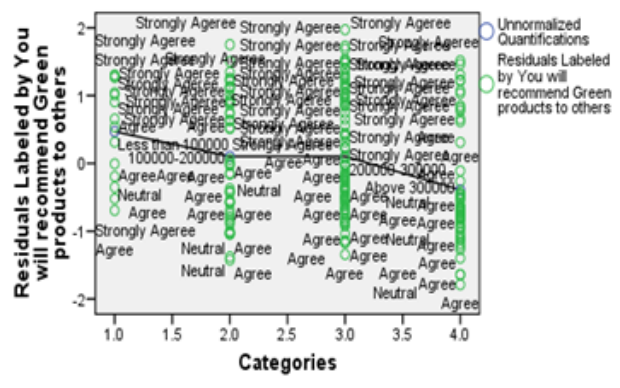

Optimal Scaling Level: Spline Ordinal (degree 2, interior knots 2)

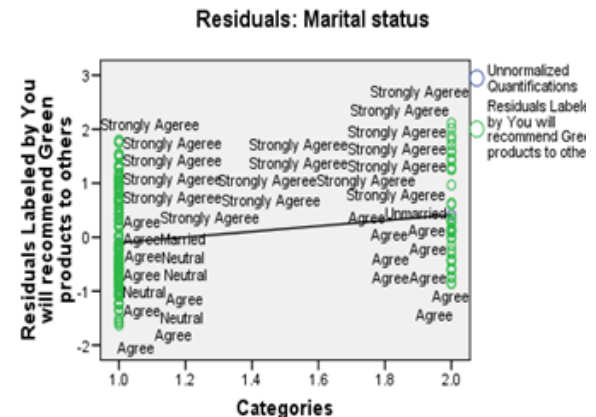

Optimal Scaling Level: Spline Ordinal (degree 2, interior knots 0).

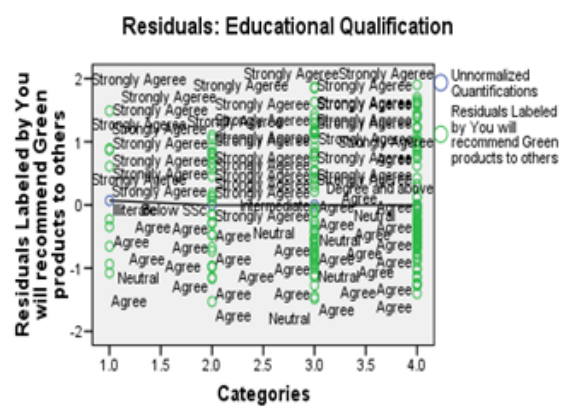

Optimal Scaling Level: Spline Ordinal (degree 2, interior knots 2).

Figure 2: Residual Plots

\section{Conceptual Mapping}

Based on the observation and findings of the study the researcher proposes a conceptual model presented in Fig 2. Green purchase and consumption relies on both the internal as well as external factors of the environment, while a company should provide a good combination of green product mix, environmental variables contributes in getting awareness about green marketing. Demography of an individual also plays an important role in deciding a green product purchase. People may get satisfied or not while using a particular green product; the decision to recommend or not to recommend totally relies on onesusage and satisfaction level with the product. 


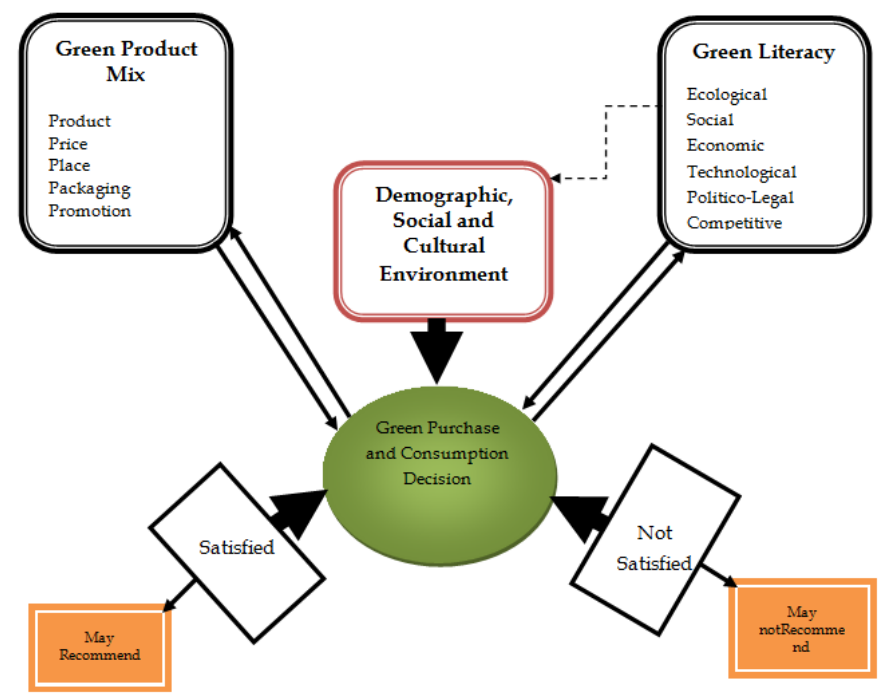

Figure 3Factors' Affecting Green Purchase Decision and Consumption

\section{Suggestions and Conclusion}

The role of modern business: To provide ever better goods and services in a way that is profitable, ethical and respects the environment, individuals and the communities in which it operates.

Tomorrow's Company, 2007

Green marketing is a beautiful concept to adopt and our marketers have the responsibility to make the consumers understand the need for and benefits of green marketing. Consumers are willing to pay more to maintain a cleaner and greener environment. Green marketing is still in its infancy and a lot of research is to be done on green marketing to fully explore it (Jamge, 2012).Jacob and Cherian,(2012) suggested that green marketing is a continuous process that requires constant inputs from the suppliers, government legislations and policies and the people. This is required so that the businesses green marketing strategy can be aligned to the target markets and so it can gain a sustainable competitive advantage. It is important that strategies and policies in relation to green products be developed and implemented so as to guide and help the retailers and customers towards a green change.

Due to the growing concern of environmental protection, consumers are now changing their behavior to integrate environmental considerations into lifestyle choices. This change includes consumers' purchasing decisions based upon how well products satisfy their needs and how these products save the natural environment (Kheiry and Nakhaei, 2012).Businesses should concentrate on focusing on developing a green product that have a demand from the general public and which also aligns to the company's core positioning. Advances in green marketing also include, packaging made from recycled paper, phosphate free detergents, refillable containers and bottles using less plastic etc. Green marketing although not so common, opinion polls consistently show that consumers would prefer to chose a green product over one that is less friendly to the environment (karpagam and Jaikumar, 2010). So we must Learn Green, Make Green, Sell Greenand customers will have to purchase Green.

\section{References}

[1]. Arbuthnott, J. and Lingg, S. (1975), "A comparison of French and American Environmental Behaviors, knowledge and attitudes", International Journal of Psychology, 4(10): 275-281.

[2]. Balderjahn, I. (1988), "Personality Variables and Environmental Attitudes as Predictors of EcologicallyResponsible Consumption Patterns", Journal of Business Research, 17: 51-56.

[3]. Eriksson, C. (2004),"Can Green Consumerism Replace Environmental Regulation?-A Differentiated-Products Example”, Resource and Energy Economics, 26(3): 281-293.

[4]. Follows, S.B. and Jobber, D. (2000),“Environmentally Responsible Purchase Behavior: A Test of aConsumer Model”,European Journal of Marketing, 34(5/6): $723-746$.

[5]. Gadekar, A. V. and Gadekar, R. A. (2012), "Study of Impact of Green Marketing on Sale", Research Journal of Social Science and Management, 1(10): 27-31.

[6]. Gadenne, D., Sharma, B., Kerr, D., and Smith, T. (2011),“The Influence of Consumers' Environmental Beliefs and on Energy Saving Behaviors",Energy Policy, 39(12): 7684-7694.

[7]. Hair, J. F., Anderson, R. E., Tathan, R. L. and Black, W. C. (1998),“Multivariate Data Analysis”, $5^{\text {th }}$ edition. Prentice-Hall International, Inc. USA.

[8]. Hoyer, W. andMacInnis, D. (2004),“Consumer Behavior”,Houghton Mifflin, Boston, MA.

[9]. Jacob, J. and Cherian, J. (2012), “Green Marketing: A Study of Consumers' Attitude towardsEnvironment Friendly Products”,Asian Social Science, 8(12): 117-126. 
[10]. Johri, M. L. and Kanothip, S. (1998), “Green Marketing of Cosmetics and Toiletries in Thailand”,Journal of Consumer Marketing, 15(3): $265-281$.

[11]. Jamge, D. L. (2012), "Turning Towards the Green Marketing:A Need of the Hour in Indian Corporate Sector", Indian Streams Research Journal,2(8): 1-5.

[12]. Karpagam, M. and Jaikumar, G. (2010), “Green Management Theory and Applications”, Ane Books Pvt. Ltd., New Delhi.

[13]. Kassaye, W. W. and Dharmeda, V.(1992)“Balancing Traditional Packaging Functions with the New Green Packaging Concerns", Advanced Management Journal, Vol.57(4), pp. 15-23.

[14]. Kheiry, B. and Nakhaei, A. (2012) "Consumers' Green Purchase Decision: An Examination of Environmental Beliefs, Environmental Literacy and Demographics”, International Journal of Marketing and Technology, Vol. 2(9), pp. 171-183.

[15]. Kotler, P. and Zaltman, G., (1971) “Social Marketing: An Approach to Planned Social Change,” Journal of Marketing, Vol. 25, pp. 3-12.

[16]. Lee, K. (2008)“Opportunities for Green Marketing: Young Consumers”,Marketing Intelligence \& Planning, Vol. 26(6), pp. 573586.

[17]. Lee, K. (2009) "Gender differences in Hong Kong Adolescent Consumers Green Purchasing Behavior",Journalof Consumer Marketing, Vol. 26(2), pp. 87-96.

[18]. Lyer, G. (1999)“Business, Customers and Sustainable Living in an Interconnected World: A Multilateral EcocentricApproach",Journal of Business Ethics, Vol. 20(4), 273-288.

[19]. Mohanasundaram, V., (2012)“'Green Marketing - Challenges and Opportunities”,ZenithInternational Journal of Multidisciplinary Research, Vol.2(4), pp. 66-73.

[20]. Ottman, J.A. (1993), Green Marketing: Challenges \& Opportunities, NTC Business Books, Chicago, IL.

[21]. Rahbar, E., and Wahid, N. A. (2011) “Investigation of Green Marketing Tools' Effect on Consumers' Purchase Behavior", Business Strategy Series, Vol. 12(2), pp. 73-83.

[22]. Rashid N. A. (2009) Awareness of eco-label in Malaysia's green marketing initiative. International Journal of Business and Management, 4(8), 132-141.

[23]. Roy, H. (2012) "Perception, Future and Awareness of Green Marketing in "Middle Class" Segment in Kolkata, India", International Journal of Business and Management Tomorrow, Vol. 2 No. 10, pp. 1-8.

[24]. Simintiras, A. C., Schlegelmilch, B. B. and Diamantopoulos, A. (1994) 'Greening' the Marketing Mix:a Review of the Literature and an Agenda for Future Research. In: McDonagh P, Prothero A, editors. Green Management A Reader. London: The Dryden Press; 1994, pp. 413-34.

[25]. Subhani, M. I., Hasan, S. A., Osman, A. and Rudhani, S. W. A. (2012) "The Crux of Green Marketing: An Empirical Effusive Study", European Journal of Social Sciences, Vol.27(3), pp. 425-435.

[26]. Vernekar, S. S. and Wadhwa, P. (2011) "Green ConsumptionAn Empirical Study of Consumers Attitudes andPerception Regarding Eco-Friendly FMCG Products, with Special Reference to Delhi and NCR Region”, Opinion, Vol. 1(1), pp.64-74.

[27]. Wulf, K. D., \& Schroder, G. O. (2003)“Assessing the Impact of a Retailer's Relationship Efforts on Consumers' Attitudes and Behavior",Journal of Retailing and Consumer Services, Vol.10 (2), pp. 95-108.

\section{Further Readings}

[28]. Crane, A. (2000) "Facing the Backlash: Green Marketing and Strategic Re-Orientation in the 1990s", Journal of Strategic Marketing, Vol.8, No.3, pp. 277-96.

[29]. Elkington, J. (1994) "Towards the Sustainable Corporation: Win Win Business Strategies for Sustainable Development", California Management Review, Vol. 36, No.2 pp. 90-100. 